Article

\title{
Characterization of Residual Biomasses and Its Application for the Removal of Lead Ions from Aqueous Solution
}

\author{
Candelaria Tejada-Tovar ${ }^{1}$, Angel Darío Gonzalez-Delgado ${ }^{2, *}$ and Angel Villabona-Ortiz ${ }^{1}$ \\ 1 Chemical Engineering Department, Process Design and Biomass Utilization Research Group (IDAB), \\ University of Cartagena, Avenida del Consulado St. 30, Cartagena de Indias 130015, Colombia; \\ ctejadat@unicartagena.edu.co (C.T.-T.); avillabonao@unicartagena.edu.co (A.V.-O.) \\ 2 Chemical Engineering Department, Nanomaterials and Computer Aided Process Engineering Research \\ Group (NIPAC), University of Cartagena, Avenida del Consulado St. 30, \\ Cartagena de Indias 130015, Colombia \\ * Correspondence: agonzalezd1@unicartagena.edu.co
}

Received: 10 July 2019; Accepted: 19 October 2019; Published: 23 October 2019

\begin{abstract}
The removal of water pollutants has been widely addressed for the conservation of the environment, and novel materials are being developed as adsorbent to address this issue. In this work, different residual biomasses were employed to prepare biosorbents applied to lead ( $\mathrm{Pb}(\mathrm{II}))$ ion uptake. The choice of cassava peels (CP), banana peels (BP), yam peels (YP), and oil palm bagasse (OPB) was made due to the availability of such biomasses in the Department of Bolivar (Colombia), derived from agro-industrial activities. The materials were characterized by ultimate and proximate analysis, Fourier Transform Infrared Spectroscopy (FTIR), Brunauer-Emmett-Teller analysis (BET), Scanning Electron Microscopy (SEM), and Energy Dispersive X-Ray Spectroscopy (EDS) in order to determine the physicochemical properties of bioadsorbents. The adsorption tests were carried out in batch mode, keeping the initial metal concentration at $100 \mathrm{ppm}$, temperature at $30^{\circ} \mathrm{C}$, particle size at $1 \mathrm{~mm}$, and solution $\mathrm{pH}$ at 6 . The experimental results were adjusted to kinetic and isotherm models to determine the adsorption mechanism. The remaining concentration of $\mathrm{Pb}$ (II) in solution was measured by atomic absorption at $217 \mathrm{~nm}$. The functional groups identified in FTIR spectra are characteristic of lignocellulosic materials. A high surface area was found for all biomaterials with the exception of yam peels. A low pore volume and size, related to the mesoporous structure of these materials, make these bioadsorbents a suitable alternative for liquid phase adsorption, since they facilitate the diffusion of $\mathrm{Pb}$ (II) ions onto the adsorbent structure. Both FTIR and EDS techniques confirmed ion precipitation onto adsorbent materials after the adsorption process. The adsorption tests reported efficiency values above $80 \%$ for $\mathrm{YP}, \mathrm{BP}$, and $\mathrm{CP}$, indicating a good uptake of $\mathrm{Pb}$ (II) ions from aqueous solution. The results reported that Freundlich isotherm and pseudo-second order best fit experimental data, suggesting that the adsorption process is governed by chemical reactions and multilayer uptake. The future prospective of this work lies in the identification of alternatives to reuse $\mathrm{Pb}(\mathrm{II})$-contaminated biomasses after heavy metal adsorption, such as material immobilization.
\end{abstract}

Keywords: adsorption; environmental remediation; biomasses; heavy metals

\section{Introduction}

The contamination of aquatic ecosystems has been associated with increasing anthropogenic activities that discharge untreated wastewater into the environment [1]. The changes in water chemistry owning pollution issues have serious effects on living organisms, especially aquatic biota directly, and human beings indirectly [2,3]. Most industrial effluents are composed of organic and inorganic 
pollutants which may affect the public health; heavy metals pollutants are especially considered a serious environmental issue affecting soil, ecosystems, and surface water [4]. The major sources of such contaminants are the refining industry, batteries, tanneries, and the paint industry. Lead is one of the most significant environmental pollutants, due to its effects on health, causing damage to the central nervous system, gastrointestinal diseases, headaches, dizziness, diarrhea, and vomiting [5]. The toxic effects of lead have been investigated in several contributions, e.g., a Microtox aasay ${ }^{\circledR}$ was employed to determine the toxicity levels of lead compared to three other metals, reported the following order: mercury $>$ lead $>$ cadmium $>$ arsenic [6]. According to the World Health Organization, the maximum concentration of lead allowed in drinking water is $0.01 \mathrm{mg} / \mathrm{L} \mathrm{[7].} \mathrm{To} \mathrm{reach} \mathrm{lower} \mathrm{concentrations} \mathrm{than}$ the limit, it is necessary to apply treatment methods such as adsorption, ion exchange, coagulation, and chemical precipitation, among others.

The wide range of alternatives for the removal of heavy metals is limited by high cost, low efficiency, low selectivity, or complexity [8]. The adsorption technique is known as one of the most effective methods to uptake heavy metal ions because of the availability of several high-efficient and low-cost materials with adsorption properties [9]. The selection of an adsorbent is the most important aspect during such a technique, according to the desired removal yields. Novel adsorbents have been tested to improve the selectivity, adsorption capacity, and reusability for large-scale application of traditional adsorbents [10,11]. To date, different types of agricultural biomasses have been prepared as bioadsorbents for the treatment of residual water, such as peanut shells, shrimp exoskeleton, fruit peels, and sugarcane bagasse $[12,13]$. The valorization of such biomasses by synthetizing adsorbent materials represents an attractive solution to solve disposal problems of agricultural residues [14]. Anastopoulos et al. [15] performed a literature review on the use of agricultural biomasses as bioadsorbents to decontaminate aqueous solutions. Such a contribution identified adsorption capacities from 0.38 to $820 \mathrm{mg} / \mathrm{g}$, which is highly affected by the biosorbent nature and the system metal-biosorbent.

Different materials have been also tested for the removal of lead from water using adsorption technology. Di Bitonto et al. [16] prepared amorphous titanium hydroxide and boron-doped (B-doped) sodium titanates hydrates for the removal of $\mathrm{Pb}$ (II) from water, and achieved an adsorption efficiency of $99.9 \%$. Huang et al. [17] synthesized titanate nanoflowers and evaluated their adsorption mechanism for lead uptake using isotherm and kinetic modelling. The authors reported that the Langmuir isotherm and pseudo-second order kinetic best fit the experimental data. Hu and Shipley [18] used regenerated $\mathrm{TiO}_{2}$ nanoparticles (which are released during water treatment processes) to remove heavy metal ions such as lead, and observed adsorption efficiencies greater than $94 \%$ after four cycles of regeneration using $\mathrm{pH}$ 2. These authors also evaluated the desorption process of lead, copper, and zinc from commercially-prepared $\mathrm{TiO}_{2}$ nanoparticles, obtaining yields at $\mathrm{pH} 4$ of 49,85 , and $88 \%$, respectively [19].

Other contributions select agricultural materials as the main source of adsorbents for lead removal; for example, Boeykens et al. [20] prepared adsorbents from the biomass of avocado seeds to remove lead and chromium ions from aqueous solution. They tested the adsorbent in its natural form (NB), in a chemically activated (AB) form, and with activated carbon (AC), and reported removal yields of up $80 \%$ at $\mathrm{pH}=5$ and $\mathrm{T}=25^{\circ} \mathrm{C}$. Amin et al. [21] used biochar derived from date palm waste biomass to evaluate the adsorption performance for lead and copper removal. The maximum adsorption capacity of lead $(98.9 \mathrm{mg} / \mathrm{g})$ was reached at $\mathrm{pH}=4.5$, and the Freundlich-Langmuir model best fit the adsorption data for $\mathrm{Pb}(\mathrm{II})$. Bagali et al. [22] used banana pseudostems for the removal of lead ions using a batch process, and studied the adsorption kinetics by altering the operating parameters. The authors reported an adsorption capacity of $34.21 \mathrm{mg} / \mathrm{g}$, and the pseudo second-order model showed the best fit. Alhogbi [23] prepared a green, low-cost, solid-phase adsorbent from coffee husk biomass waste in order to uptake $\mathrm{Pb}$ (II) ions, and evaluated the effect of analytical parameters. They reported high removal yields, i.e., up $98 \%$ and an adsorption capacity of $19.02 \mathrm{mg} / \mathrm{g}$, and sorption kinetics data were fit with a pseudo-second order model. Mohammed et al. [24] studied the equilibrium and thermodynamics of 
heavy metals onto activated carbon prepared from olive branches, and reported a maximum adsorption capacity of $41.32 \mathrm{~g} / \mathrm{g}$ for lead ions.

The aim of this work is to prepare bioadsorbents from biomasses in order to address disposal problems of agricultural waste and mitigate the environmental impact of heavy metal contamination. To this end, residues from yam, cassava, banana, and oil palm were selected to develop novel materials whose adsorption capacities were tested using the batch adsorption system. During the agricultural activities of tubers and fruits in the department, huge quantities of waste are generated because of the decomposition of organic products. Such lignocellulosic materials have no commercial value and represent an alarming disposal problem; hence, the preparation of bioadsorbents from agricultural biomass must be more profitable than adsorbents with high demand of raw materials. The novelty of this work lies in a comparison of the adsorption performances of different agroindustrial biomasses which are available in the Department of Bolivar in order to propose remediation alternatives for water pollution based on this removal mechanism.

\section{Aims and Objectives}

This work aims to evaluate the adsorption capacity of biomasses which are widely available in the Department of Bolivar (Colombia). The use of such biomaterials for adsorbent synthesis represents a means of waste valorization, and, at the same time, contributes to remediating aquatic ecosystems affected by heavy metal pollution.

\section{Materials and Methods}

\subsection{Experimental Materials}

The biomasses (yam peels, banana peels, cassava peels, and oil palm bagasse) were collected from a commercial market located in the Department of Bolivar. Lead nitrate $\left(\mathrm{Pb}\left(\mathrm{NO}_{3}\right)_{2}\right.$, reagent grade) was purchased from Sigma Aldrich. Sodium hydroxide (97\% purity) and hydrochloric acid were purchased to adjust solution $\mathrm{pH}$.

\subsection{Biomass Preparation}

The agricultural waste, i.e., cassava peels (CP), banana peels (BP), yam peels (YP), and oil palm bagasse (OPB), were selected because of the generation of huge quantities of biomasses owing product decomposition. No chemical or physical modification of the materials was performed, in order to avoid cost increases. The biomaterials were sent to the washing stage with deionized water in order to remove impurities and other compounds that may affect adsorption process, e.g., tannins, dyeing agents, resins, etc. Then, the biomasses were dried under solar radiation to reduce moisture content. Finally, a milling stage was required to reduce the particle size to $1 \mathrm{~mm}$ [25].

\subsection{Biomass Characterization}

Functional groups in biomasse structures were determined using an IRAinfinity-1 spectrophotometer using 32 scans over $400-4000 \mathrm{~cm}^{-1}$ in a Perkin Elmer Aanalyst 300 Atomic Absorption Spectrometer. This characterization was performed before and after the adsorption process, and $100 \mathrm{mg} \mathrm{KBr}$ was selected as reference. The surface area was measured by the analyzer software, Micromeritics ASAP 2020, which determines the adsorption isotherm of $\mathrm{N}_{2}$ at $195.8^{\circ} \mathrm{C}$ through the BET (Brunauer, S., Emmett, P., Teller, E.) equation. The physical properties of adsorbents, as well as their elemental composition, were measured with a scanning electron microscope coupled with an energy-dispersive spectroscope (SEM-EDS) model JSM-6490LV (JEOL Ltd., Medellin, Colombia). The ultimate and proximate analyses were performed to estimate the composition of carbon, hydrogen, nitrogen, ashes, pectin, cellulose, hemicellulose, and lignin, using the following methods: AOAC 949.14, AOAC 984.13 (Kjeldahl), thermogravimetry, acid digestion-thermogravimetry, digestion-thermogravimetry, and photocolorimetry [25-27]. A proximity analysis was performed to 
calculate the chemical compositions of the residual materials, including ash content and moisture. The determination of ash content during this characterization was performed based on the standard procedure of heating in a furnace at $575{ }^{\circ} \mathrm{C} \pm 250{ }^{\circ} \mathrm{C}$ [28]. A thermogravimetric analyzer model TGA/SDTA 851 (Mettler Toledo, Medellín, Colombia) was used for the determination of pectin, cellulose, hemicellulose, and lignin.

\subsection{Adsorption Study}

The adsorption process is highly affected by several parameters, such as temperature, adsorbent dosage, particle size of adsorbent, solution $\mathrm{pH}$, temperature, contact time, and stirring, among others [29]. Previous contributions developed by the authors have suggested the optimal operating conditions for lead uptake onto the selected biomasses [14,26,30,31]. In this sense, adsorption tests were performed on batch mode under $200 \mathrm{rpm}, 30^{\circ} \mathrm{C}$, using bioadsorbents of $1 \mathrm{~mm}$ particle size at $\mathrm{pH}=6$. An orbital shaker was used, the MAXQ 4450, and the pHmeter Start A221 (both provided by Thermo Fisher Scientific, Bogotá, Colombia) to reach the correct stirring speed and adjust the solution $\mathrm{pH}$. The 100-ppm aqueous solution was prepared by adding $1.598 \mathrm{~g}$ of lead nitrate- $\mathrm{Pb}\left(\mathrm{NO}_{3}\right)_{2}$ to $1000 \mathrm{~mL}$ of deionized water. After adsorption, the remaining concentration was measured by atomic absorption spectrophotometry at $217 \mathrm{~nm}$. A central composite design of the experiments was selected to conduct adsorption tests according to the random starts point provided by the Statgraphics Centurion Software 16.1.15 (developed by Statgraphics Technologies, Inc.). The removal yield was calculated by Equation (1), where $C_{0}$ is the initial concentration and $C_{f}$ is the final concentration after adsorption [32].

$$
\% \operatorname{Removal}(\mathrm{R})=\frac{C_{o}-C_{f}}{C_{o}} \times 100
$$

\subsection{Kinetic Study and Isotherm Modeling}

To perform the kinetic study, it was mixed $100 \mathrm{~mL}$ of $\mathrm{Pb}$ (II) solution at $100 \mathrm{ppm}$ with $0.5 \mathrm{~g}$ of bioadsorbents under continuous agitation at $200 \mathrm{rpm}$. Aliquots were taken every 5 min during the first $30 \mathrm{~min}$ because of the rapid adsorption mechanism before saturation. Then, the samples were taken each hour for $5 \mathrm{~h}$. The experimental data was adjusted to kinetic models (pseudo-first, pseudo-second, and Elovich) using the OriginPro 8.5 software (developed by OriginLab Corporation) to calculate the fitting parameters and correlation coefficient $\left(R^{2}\right)$. Isotherm modeling was performed for $24 \mathrm{~h}$ by varying the initial concentration of heavy metal ions $(25,50,75$, and $100 \mathrm{ppm})$ at fixed conditions: $30^{\circ} \mathrm{C}, 100 \mathrm{~mL}$ of solution, and $0.5 \mathrm{~g}$ of bioadsorbent. The Langmuir and Freundlich isotherms were selected to fit the experimental results in batch adsorption mode [14]. Tables 1 and 2 report the fitting equations used to determine both the kinetic and isotherm parameters.

Table 1. Mathematical expressions of kinetic models.

\begin{tabular}{ccc}
\hline Kinetic Model & Equation & Parameters \\
\hline Pseudo-1st-order & $q_{t}=q_{e}\left(1-e^{-k t}\right)$ & $\begin{array}{c}q_{e}, \text { Adsorption capacity at equilibrium }(\mathrm{mg} / \mathrm{g}) \\
k_{1}, \text { pseudo-1st-order constant }\left(\mathrm{min}^{-1}\right)\end{array}$ \\
\hline Pseudo-2nd-order & $q_{t}=\frac{t}{\left(\frac{1}{\left(k_{2} q_{e}^{2}\right)}\right)+\left(\frac{t}{q_{e}}\right)}$ & $\begin{array}{c}k_{2} \text { pseudo-2nd-order constant }(\mathrm{g} / \mathrm{mg} \cdot \mathrm{min}) \\
q_{e}, \text { Adsorption capacity at equilibrium }(\mathrm{mg} / \mathrm{g})\end{array}$ \\
\hline Elovich equation & $\frac{1}{\beta} \ln (\alpha \beta)+\frac{1}{\beta} \ln t$ & $\begin{array}{c}\alpha, \text { Elovich constant }(\mathrm{mg} / \mathrm{g} \mathrm{min}) \\
\beta, \text { Elovich exponent }(\mathrm{g} / \mathrm{mg})\end{array}$ \\
\hline
\end{tabular}


Table 2. Mathematical expressions of isotherm models.

\begin{tabular}{|c|c|c|}
\hline Kinetic Model & Equation & Parameters \\
\hline Langmuir & $q_{e}=q_{\max } \frac{K C_{f}}{1+K C_{f}}$ & $\begin{array}{l}q_{e}: \text { Adsorption capacity at equilibrium }(\mathrm{mg} / \mathrm{g}) ; \\
C_{f}: \text { Final concentration of heavy metals }(\mathrm{mg} / \mathrm{L}) \\
q_{\max }: \text { Maximum adsorption capacity }(\mathrm{mg} / \mathrm{g})\end{array}$ \\
\hline Freundlich & $q=K C_{e}^{\frac{1}{n}}$ & $\begin{array}{c}q: \text { Adsorption capacity }(\mathrm{mg} / \mathrm{g}) ; \\
\text { Ce: Heavy metal concentration at equilibrium }(\mathrm{mg} / \mathrm{L}) ; \\
\text { K: Freundlich constant }(\mathrm{mg} / \mathrm{g}) ; \\
n: \text { Heterogeneity factor }\end{array}$ \\
\hline
\end{tabular}

\section{Results}

\subsection{Characterization Techniques}

The adsorption process is a complex phenomenon involving many steps; therefore, many factors affect the removal yield of heavy metals from aqueous solutions. Table 3 shows the results for the ultimate and proximate analyses of the biomasses. It was found that carbon contributed most to the bioadsorbent composition, followed by hydrogen. These results were expected, due to the content of such elements in cellulose, hemicellulose, and lignin molecules. Banana peels reported the highest content of cellulose and hemicellulose, which may increase removal yields during adsorption experiments. The removal of heavy metal ions using these lignocellulosic materials is attributed to the presence of functional groups such as hydroxyl, carboxyl, and amines. In this sense, it is important to identify functional groups in bioadsorbents [33].

Table 3. Proximate and ultimate analysis for selected biomasses.

\begin{tabular}{ccccccccc}
\hline Biomass & Cellulose & Hemicellulose & Lignin & Pectin & Carbon & Nitrogen & Hydrogen & Ashes \\
\hline BP & 20.9 & 7.92 & 18.11 & 2.84 & 36.69 & 0.69 & 3.98 & 7.2 \\
CP & 18.47 & 6.01 & 2.20 & 2.84 & 36.96 & 0.26 & 3.98 & 1.58 \\
YP & 13.08 & 6.47 & 27.73 & 10.98 & 48.14 & 0.18 & 5.44 & 4.85 \\
OPB & 19.90 & 7.00 & 17.11 & 4.88 & 38.27 & 2.03 & 4.71 & 4.23 \\
\hline
\end{tabular}

The presence of the functional groups responsible for the adsorption of lead ions on the surface of bio-adsorbent materials was performed by Fourier Transformed Infrared Spectroscopy (FTIR); this technique shows bands that indicate different wavelengths which are directly proportional to the radiation energies in the infrared range. Figure 1 depicts the FTIR spectrum for bioadsorbents before and after adsorption process. The complexity of lignocellulosic materials, due to the various identified bands, was confirmed. Several peaks were identified at $3400 \mathrm{~cm}^{-1}(\mathrm{OH})$, $3390.28 \mathrm{~cm}^{-1}(\mathrm{NH}), 2931.01 \mathrm{~cm}^{-1}$ (C-C), $1652.11 \mathrm{~cm}^{-1}$ (C=C), $1420.81 \mathrm{~cm}^{-1}$ (C-C), $1339.79 \mathrm{~cm}^{-1}\left(\mathrm{NO}_{2}\right)$, and $1156.40 \mathrm{~cm}^{-1}$ (C-O) for all bioadsorbents. After the adsorption process, changes were observed in the width and stretch of some of the bands, especially at $3390 \mathrm{~cm}^{-1}(\mathrm{NH}), 2361.19 \mathrm{~cm}^{-1}(-\mathrm{C} \equiv \mathrm{N})$, $1650.45 \mathrm{~cm}^{-1}(\mathrm{C}=\mathrm{C}), 1020.66 \mathrm{~cm}^{-1}(\mathrm{OH})$, and $1156.55 \mathrm{~cm}^{-1}$ (sulfonamides). Such a phenomenon was attributed to the bonds formed between the heavy metal ions and the active sites of the materials [34]. 


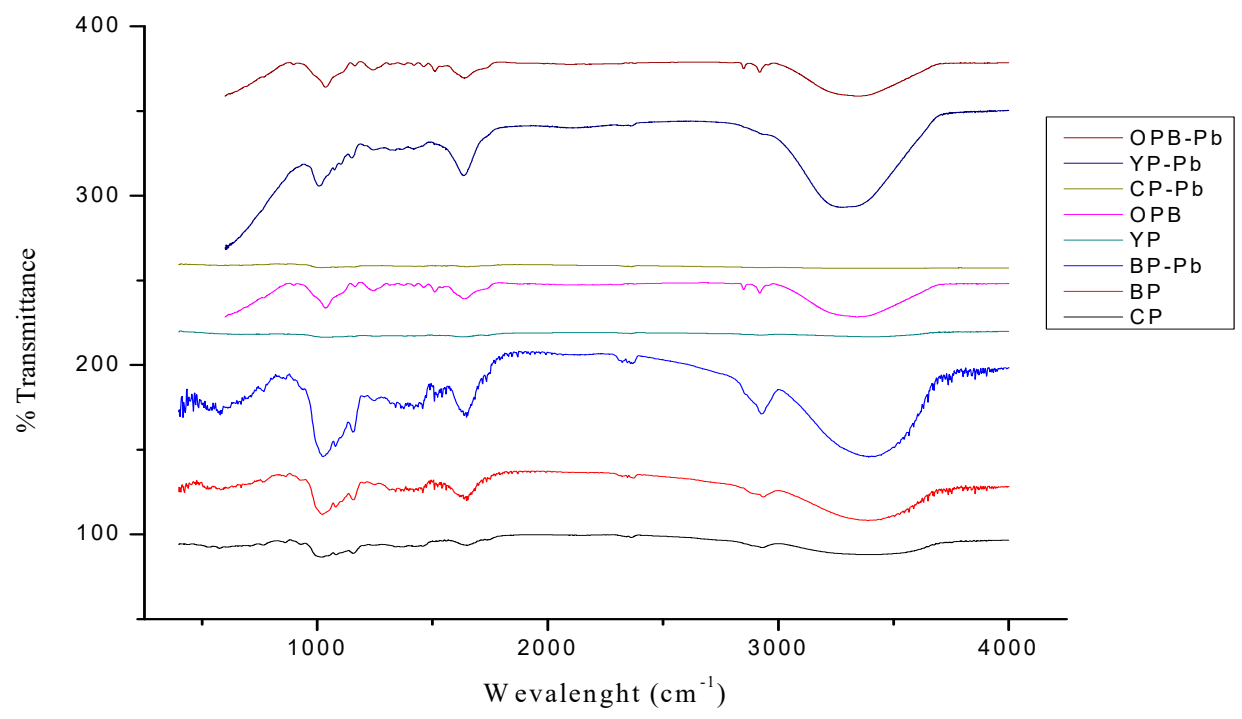

Figure 1. Spectrum from Fourier Transform Infrared Spectroscopy of biomasses before and after the $\mathrm{Pb}$ (II) adsorption process.

The surface chemistry and pore structure of adsorbents make key contributions to an efficient adsorption process. Table 4 shows the results of a Brunauer-Emmett-Teller (BET) analysis. The banana peel biomass reported the highest surface area, despite lignocellulosic residues generally having low surface areas due to the nature of cellulose and hemicellulose [11]. For all biomasses, pore volume was low, which was attributed to the structure of cellulose, lignocellulose, and lignin, which are characterized by reduced quantities of pores and blocked pores [35]. In addition, all biomasses showed pore sizes between $2-50 \mathrm{~nm}$, indicating that these materials are mesoporous and can be appropriate for use as adsorbents in the aqueous phase, because they facilitate the diffusion of adsorbates into adsorbent structures [36,37].

Table 4. Surface area and porosity analysis of biomasses.

\begin{tabular}{cccc}
\hline Biomass & Surface Area $\left(\mathbf{m}^{2} / \mathbf{g}\right)$ & Pore Volume $\left(\mathrm{cm}^{3} / \mathbf{g}\right)$ & Pore Size $(\mathbf{n m})$ \\
\hline Yam peel & 0.9463 & 0.005452 & 23.04419 \\
Banana peel & 3.0889 & 0.004977 & 6.44567 \\
Oil palm bagasse & 2.7317 & 0.011207 & 16.410 \\
Cassava peel & 2.0509 & 0.002233 & 4.35428 \\
\hline
\end{tabular}

The adsorption-desorption isotherms of $\mathrm{N}_{2}$ are shown in Figure 2 for $\mathrm{YP}, \mathrm{OPB}, \mathrm{BP}$, and $\mathrm{CP}$ biomasses. For the YP and OPB biomasses (see Figure 2a,b), the isotherms were classified as type II, i.e., associated with a mesoporous structure, confirming the results obtained by a surface area analysis. A mesoporous structure is extremely beneficial for metal ion transportation from aqueous solution onto the adsorbent surface, which increases the adsorption capacity. Therefore, many functional groups in this type of material can provide efficient active sites at the interface of the solid-liquid surface for higher adsorption capacities for Pb(II) uptake [38]. For BP and CP biomasses (see Figure 2c,d), isotherms feature an open curve that is common in microporous materials with a slightly mesoporous tendency. The isotherms for both biomasses showed types I and II, and a hysteresis type H3. A large increase in the adsorption of $\mathrm{N}_{2}$ to $\mathrm{P} / \mathrm{P}_{0}>0.9$ was found, suggesting that the measured surface area coincides with the external surface area of banana and cassava peels, which demonstrates the existence of micropores and mesopores [39]. 

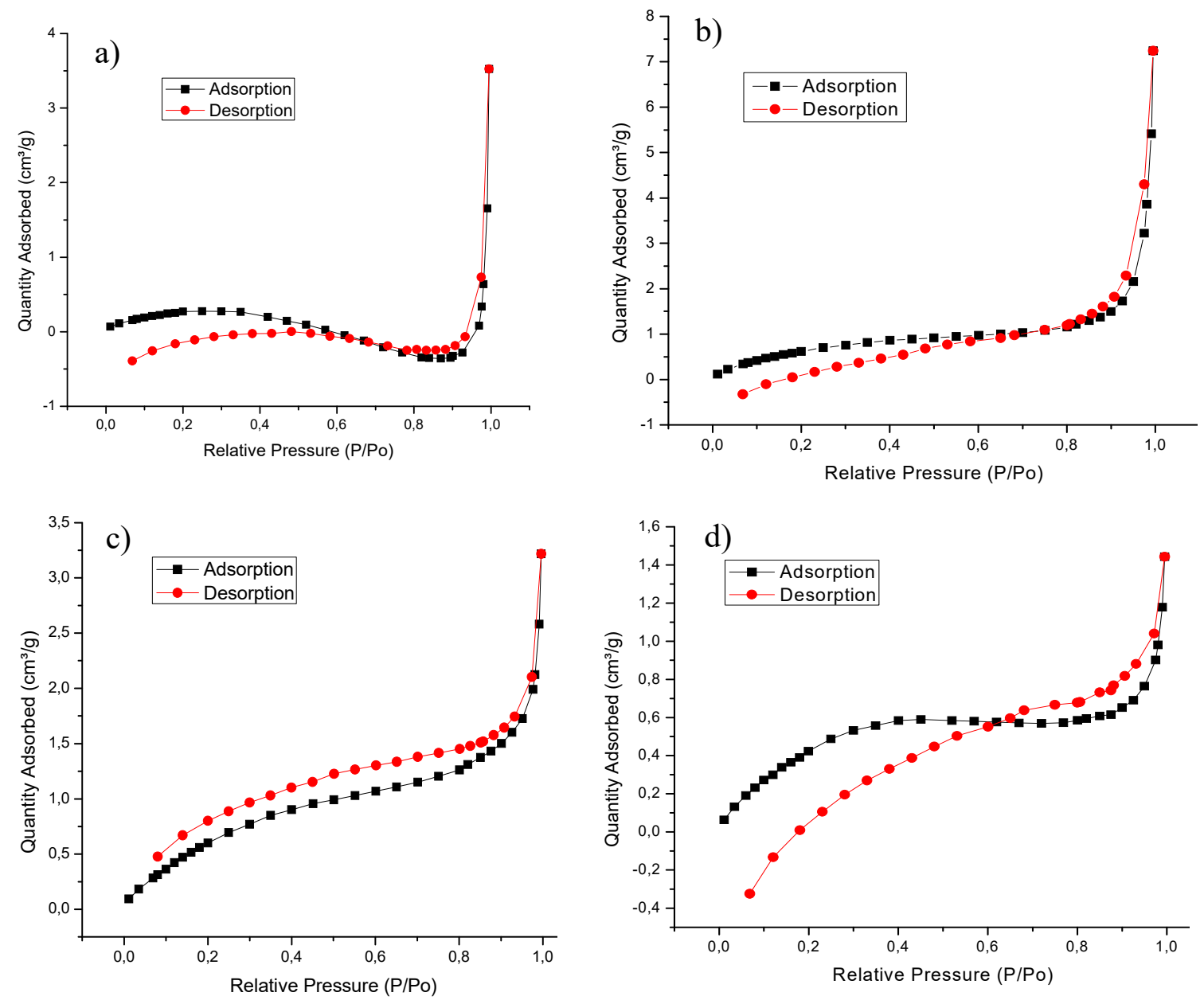

Figure 2. Adsorption-desorption isotherm for: (a) yam peels, (b) oil palm bagasse, (c) banana peels, and (d) cassava peels.

Figure $3 \mathrm{a}$, b show the SEM micrographs of yam and cassava peels, that present irregular and porous surfaces, allowing better heterogeneous biosorption to occur due to the large interface. For banana peels (see Figure 3c), a defined appearance was observed in the form of cylinders that were agglomerated with each other. For oil palm bagasse (see Figure 3d), the morphology was fibrous with a porosity that is typical of lignocellulosic materials [40,41].

Figure 4 shows the SEM micrographs for biomasses after batch adsorption experiments. It was found that $\mathrm{Pb}$ (II) ions were adsorbed onto the surface of banana peel biomasses according to an electrostatic attraction mechanism. However, on the surface of the $\mathrm{YC}, \mathrm{CP}$, and $\mathrm{OPB}$ biomasses, agglomerations of $\mathrm{Pb}(\mathrm{II})$ ions were observed, which may be attributed to the formation of microprecipitated complexes or chelates on the samples [42]. 

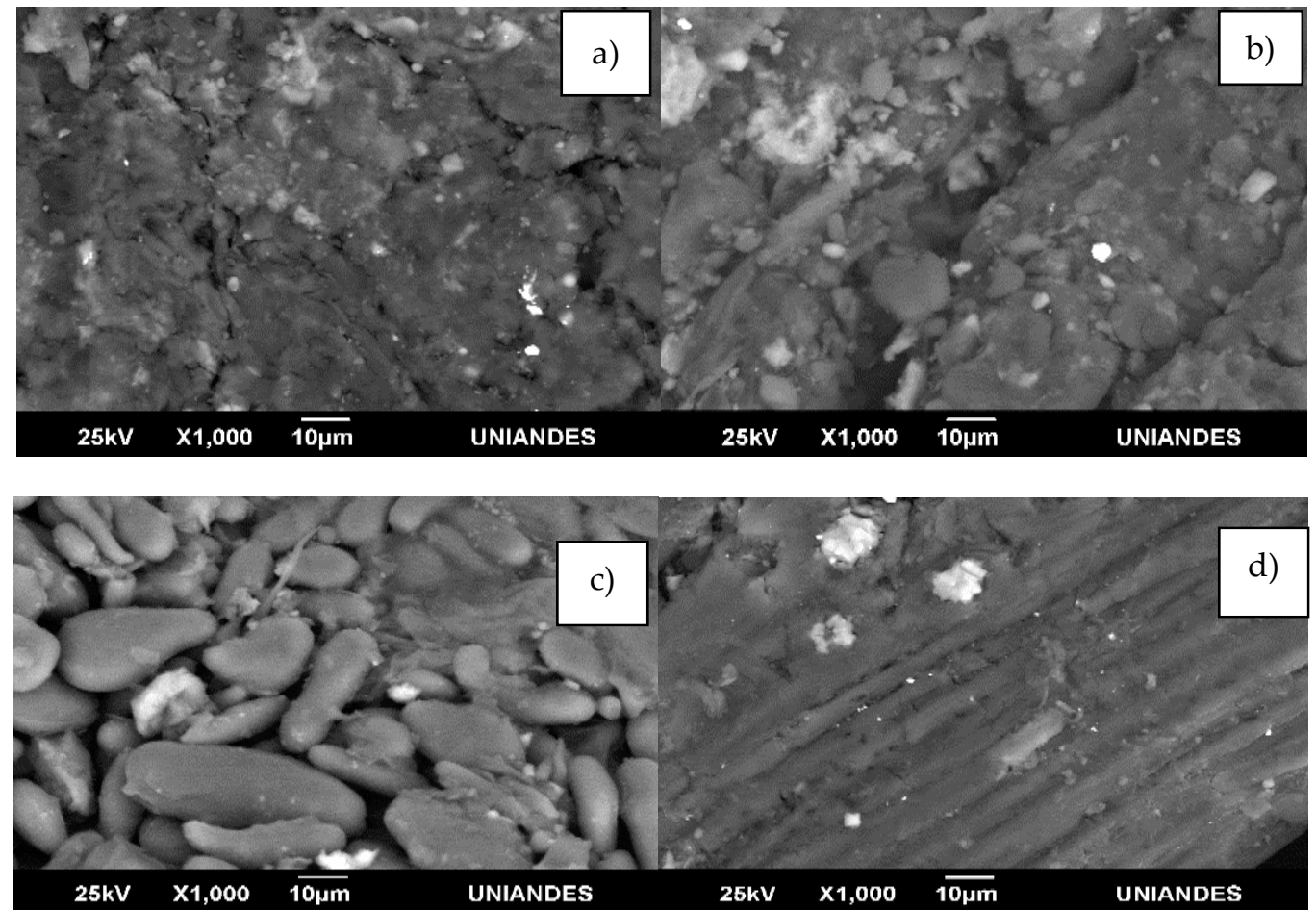

Figure 3. Micrographs from Scanning Electron Microscope before the adsorption process: (a) YP, (b) CP, (c) BP, and (d) OPB biomasses.
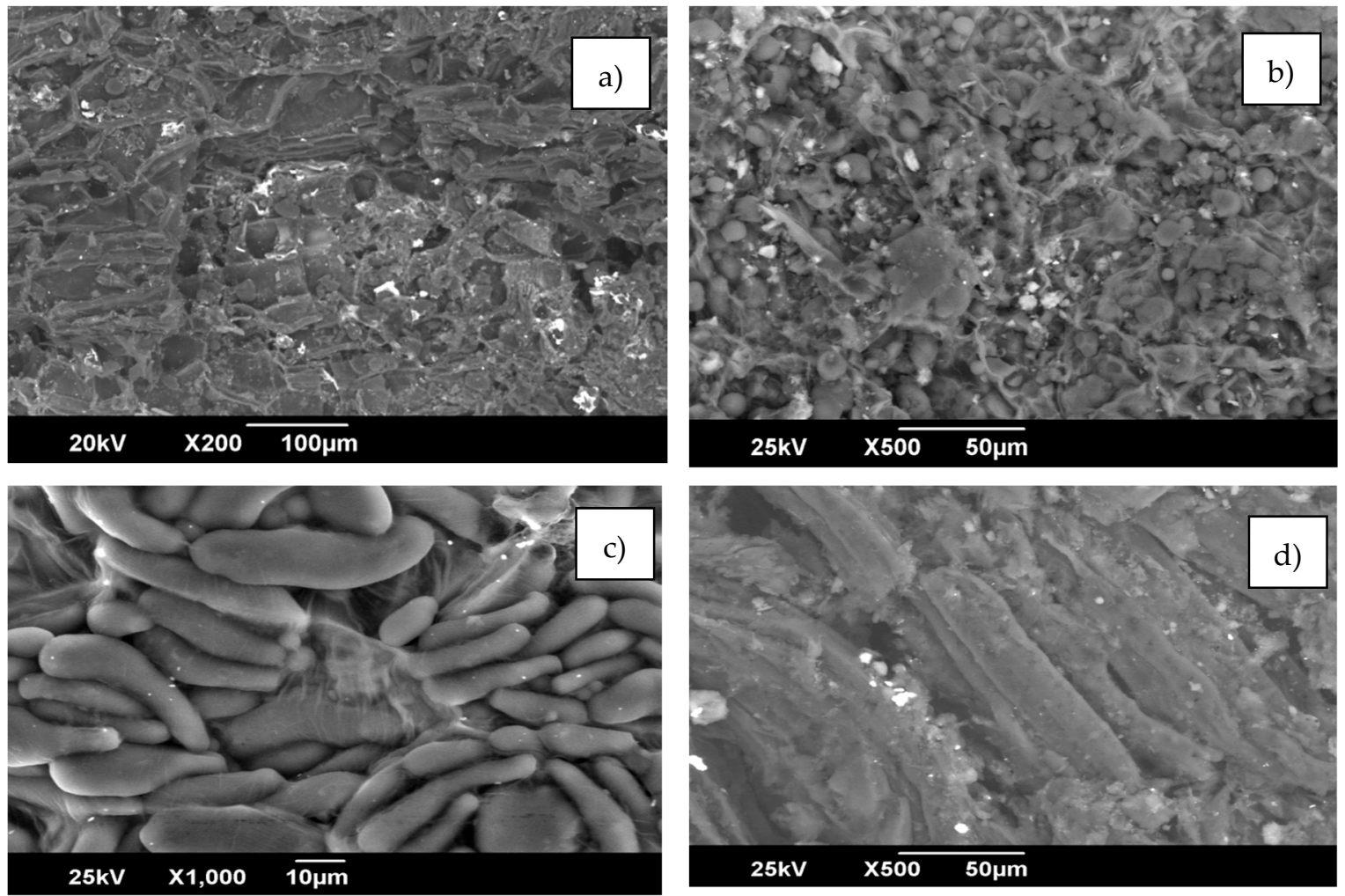

Figure 4. Micrographs from Scanning Electron Microscope after adsorption process: (a) YP, (b) CP, (c) BP, and (d) OPB biomasses. 
Figure 5 shows the spectrogram and elemental composition of the selected biomasses obtained by EDS analysis. The results revealed that carbon and oxygen contribute most to the elemental composition of all biomasses, which is attributed to the organic nature of lignocellulosic residues. For the YP biomass (see Figure 5a), the elemental composition by atomic weight is as follows: 57.07\% C, $39.05 \% \mathrm{O}$, and $1.65 \%$ of $\mathrm{K}$ and other elements in small proportions, i.e., $\mathrm{Si}, \mathrm{P}, \mathrm{S}, \mathrm{Ca}, \mathrm{Fe}$, and $\mathrm{Cu}$. For the BP biomass (see Figure $5 \mathrm{~b}$ ), the composition was: $75.18 \% \mathrm{C}, 23.34 \% \mathrm{O}$, and $1.11 \%$ of $\mathrm{K}, \mathrm{Al}$, and $\mathrm{Cl}$. For the CP biomass (see Figure 5c), 73.56\% C, and $24.97 \%$ of O, Al, Si, S, K, Ca, and Fe. For the OPB biomass (see Figure 5d), 59.07\% C, 38.85\% O, and $1.92 \%$ of $\mathrm{Si}, \mathrm{Ca}$, and $\mathrm{Cu}$.
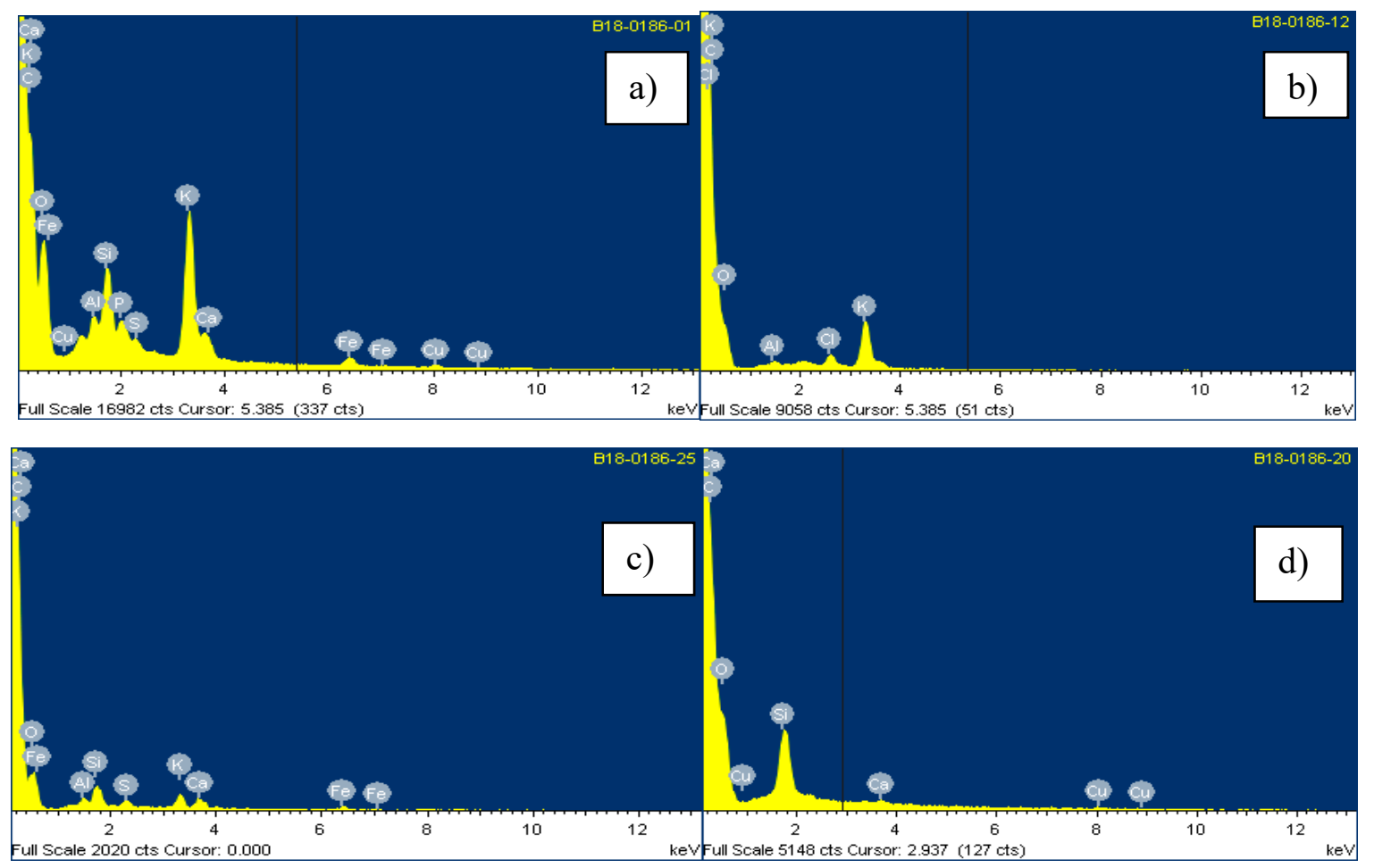

Figure 5. Energy Dispersive X-Ray spectrogram of: (a) YP, (b) CP, (c) BP, and (d) OPB biomasses before the adsorption process.

Figure 6 shows the spectrogram and elemental composition of the selected biomasses obtained by $\mathrm{EDS}$ analysis after the $\mathrm{Pb}(\mathrm{II})$ adsorption process. Heavy metal ion precipitation was observed onto the adsorption surface with a mass weight percentage of $0.54 \%$ for YP (see Figure $6 a$ ), $0.49 \%$ of BP (see Figure 6c), and OPB (see Figure 6d). The biomass CP reported the highest composition of precipitated ions with $0.72 \%$ (see Figure $6 \mathrm{~b}$ ). The disappearance of some metals present in smaller proportions, such as $\mathrm{Fe}, \mathrm{P}$, and $\mathrm{Cu}$, was observed, as was a significant decrease in the presence of $\mathrm{K}$, $\mathrm{Al}, \mathrm{Si}$, and $\mathrm{O}$. Such results may be attributed to the formation of bonds between the active sites of lignocellulosic materials and ions. In addition, there was a significant increase in the presence of $C$ for all biomaterials, which was due to the presence of active sites without saturation at the time of taking the sample. The above serves as a good indicator for the removal capacity of the bio-adsorbents [43]. 

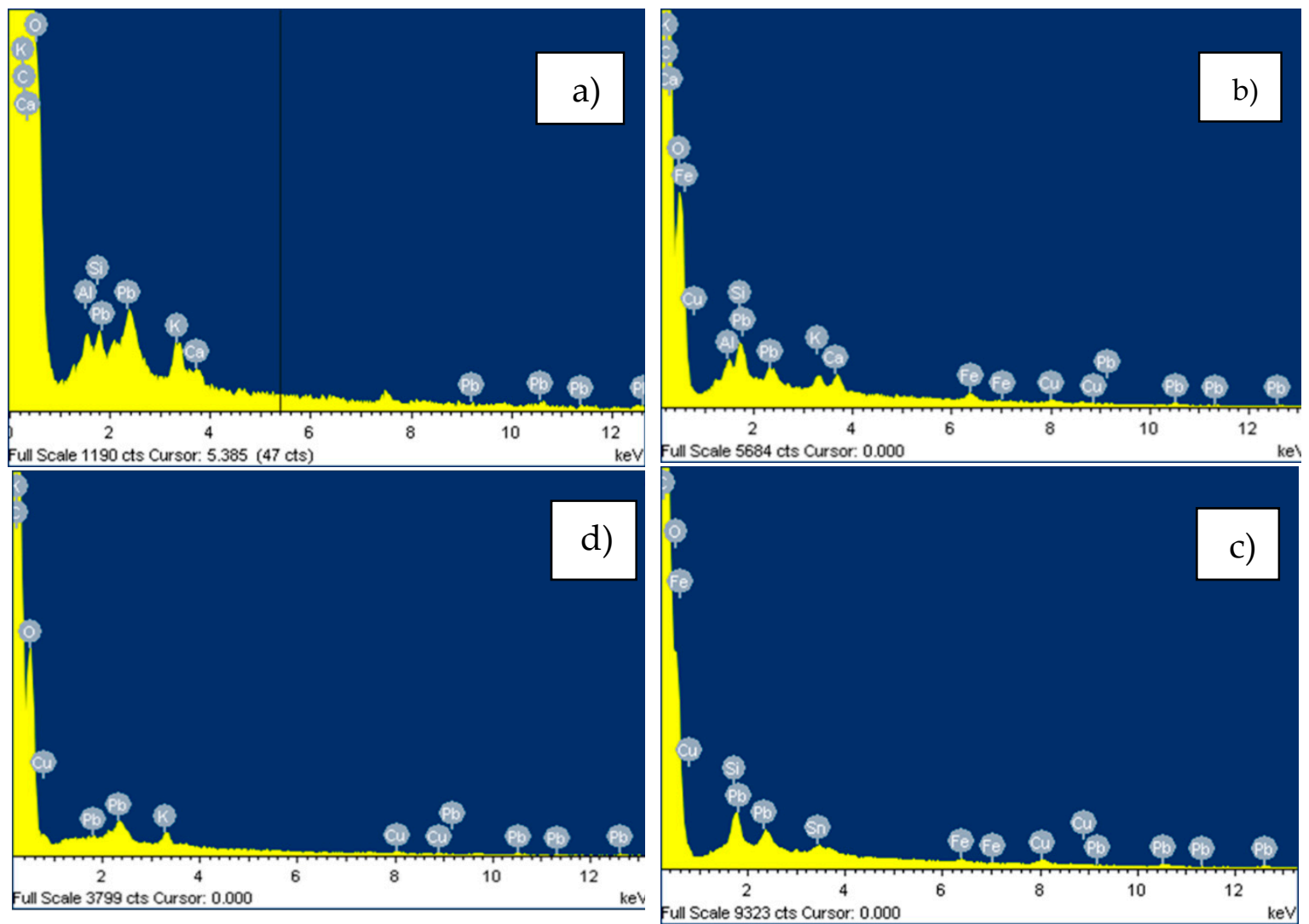

Figure 6. Energy Dispersive X-Ray spectrogram of: (a) YP, (b) CP, (c) BP, and (d) OPB biomasses after the adsorption process.

\subsection{Adsorption Tests}

The removal yields calculated by Equation (1) after the adsorption process are shown in Table 5 . The YP, CP, and BP biomasses reported the highest removal yields (above $80 \%$ ) for $\mathrm{Pb}$ (II) ion uptake, which can be attributed to the high surface area and small pore size increasing the adsorption properties of such materials; this is consistent with the results reported in Figure 5, corresponding to the EDS analyses after the adsorption process [44]. The oil palm bagasse biomass reported a removal yield of $39.41 \%$, owing to the morphology of this lignocellulosic waste with the highest pore volume. The peel biomasses showed irregular morphologies, which is a desirable characteristic of adsorbents, due to the availability of active sites to uptake heavy metal ions [45].

Table 5. Adsorption results of lead ions onto biomass-derived adsorbents.

\begin{tabular}{cccc}
\hline Heavy Metal & Adsorbent & Removal Yield (\%) & Metal Uptake (mg/g) \\
\hline \multirow{3}{*}{$\mathrm{Pb}(\mathrm{II})$} & Yam peel & 81.24 & 82.24 \\
& Banana peel & 90.12 & 91.12 \\
& Cassava peel & 98.19 & 99.19 \\
& Oil palm bagasse & 39.41 & 40.41 \\
\hline
\end{tabular}

\subsection{Kinetics and Adsorption Isotherms}

A kinetic study was carried out to analyze the adsorption performance over time. The fitting parameters of the selected models were estimated by non-linear fitting, and are listed in Table 6; it was found that the pseudo second order model best described the adsorption kinetics of $\mathrm{Pb}(\mathrm{II})$ ions onto the $\mathrm{CP}, \mathrm{YP}, \mathrm{BP}$, and OBP bioadsorbents, based on the correlation coefficient values. The fitting of experimental data to this model indicated that the process was governed by chemical adsorption, 
due to the formation of chemical bonds between the adsorbent and the adsorbate at the active sites. According to the value estimated for constant $\mathrm{K}_{2}$, it was shown that the initial sorption rate for $\mathrm{Pb}$ (I) ions over the $\mathrm{CP}$ biomass was also high, achieving high adsorption efficiency $[37,46]$.

Table 6. Fitting parameters for kinetic models.

\begin{tabular}{cccccc}
\hline Model & Parameter & CP & YP & BP & OBP \\
\hline \multirow{3}{*}{ Pseudo-first order } & $q_{e 1}(\mathrm{mg} / \mathrm{g})$ & 17.79 & 19.82 & 19.54 & 19.92 \\
& $k_{1}\left(\mathrm{~min}^{-1}\right)$ & 249.37 & 1.53 & 1.276 & 0.38 \\
& $\mathrm{R}^{2}$ & 0.996 & 0.943 & 0.932 & 0.945 \\
\hline \multirow{3}{*}{ Pseudo-second order } & $k_{2}(\mathrm{~g} / \mathrm{mg} * \mathrm{~min})$ & 1662.33 & 0.13 & 0.15 & 0.224 \\
& $q_{e}(\mathrm{mg} / \mathrm{g})$ & 17.79 & 19.97 & 19.68 & 19.97 \\
& $\mathrm{R}^{2}$ & 0.999 & 0.967 & 0.978 & 0.976 \\
\hline \multirow{2}{*}{ Elovich } & $\alpha\left(\mathrm{mmol} \cdot \mathrm{g}^{-1} \cdot \mathrm{min}^{-1}\right)$ & $2,070,197,227$ & $2.47 \times 10^{98}$ & $2.39 \times 10^{87}$ & $1.90 \times 10^{107}$ \\
& $\beta\left(\mathrm{g} / \mathrm{mg}^{2}\right.$ & 1.48 & 11.78 & 11.56 & 12.78 \\
& $\mathrm{R}^{2}$ & 0.853 & 0.898 & 0.896 & 0.898 \\
\hline
\end{tabular}

The fitting parameters for adsorption isotherms are reported in Table 7. It was found that the Freundlich model reached the highest $\mathrm{R}^{2}$, indicating that bioadsorbent surfaces are heterogeneous, which is consistent with the results obtained during biomass characterizations. Also, the adsorption mechanism seems to be multilayered, with a non-uniform distribution of heat on the surface of the adsorbents, and the removal of $\mathrm{Pb}(\mathrm{II})$ ions occurred by chemisorption $[34,47]$. The Freundlich parameter (n) reached a value of 1.87 for the OBP biomass, suggesting that the chemical bonds formed between $\mathrm{Pb}(\mathrm{II})$ ions and $\mathrm{OBP}$ were strong, and that the adsorption process was favorable. On the other hand, the values of $\mathrm{n}$ for $\mathrm{CP}, \mathrm{YP}$, and $\mathrm{BP}$ were relatively low, which indicated that the binding of $\mathrm{Pb}(\mathrm{II})$ ions onto adsorbent surface was weak [14,43].

It is important to point out that this research was limited to the adsorption experiments of lead ions onto four different residual materials; desorption cycles were not performed. However, hydrochloric and nitric acids can be used for desorbing under concentrations ranging from 0.1-1 M [48]. Despite efforts to recover the adsorbent, final disposal of contaminated biomass at the end of its useful life presents a challenging issue. The application of cement-based immobilization technologies may represent an attractive solution to such a problem. In addition, the presence of soluble organic compounds in the treated water presents another field for prospective research.

Table 7. Fitting parameters for isotherm models.

\begin{tabular}{cccccc}
\hline Model & Parameter & $\mathbf{C P}$ & YP & BP & OBP \\
\hline \multirow{3}{*}{ Langmuir } & $q_{\max }(\mathrm{mg} / \mathrm{g})$ & 11.79 & 98.36 & 18.96 & 99.73 \\
& $C_{f}(\mathrm{~L} / \mathrm{g})$ & $7,246,598.09$ & 0.16 & 724,09 & 0.05 \\
& $\mathrm{R}^{2}$ & 0.713 & 0.985 & 0.824 & 0.954 \\
\hline \multirow{3}{*}{ Freundlich } & $\mathrm{K}(\mathrm{mg} / \mathrm{g})$ & 9.57 & 13.42 & 14.78 & 8.38 \\
& $\mathrm{n}$ & 0.242 & 0.86 & 0.376 & 1.87 \\
& $\mathrm{R}^{2}$ & 0.972 & 0.999 & 0.982 & 0.835 \\
\hline
\end{tabular}

\section{Conclusions}

The adsorption of $\mathrm{Pb}(\mathrm{II})$ ions from an aqueous solution using lignocellulosic waste such as cassava peels, banana peels, yam peels, and oil palm bagasse revealed promising results for the application of such materials on the treatment of wastewater. The ultimate, proximate, and FTIR analyses showed that the structures of the adsorbents were characteristic of lignocellulosic materials. The characterization techniques of BET, SEM, and EDS revealed the mesoporous characteristics of all biomasses, as well as, high carbon and oxygen contents. EDS and FTIR analyses confirmed the precipitation of $\mathrm{Pb}$ on the evaluated adsorbent materials. The highest removal yields were achieved by the CP biomass $(98.19 \%)$, 
followed by the BP (90.12\%), which may be attributed to their irregular morphologies, small pore size, and high surface area. For the OPB biomass, novel chemical configurations must be considered to increase the adsorption capacity. The fitting of adsorption data to the Freundlich isotherm model and pseudo-second order kinetic indicated that $\mathrm{Pb}$ (II) adsorption obeyed chemical reactions, and that most of the process occurs within the multilayered pores.

Author Contributions: C.T.-T., A.D.G.-D. and A.V.-O. conceived and designed the paper, and wrote the Introduction and Materials and Methods. C.T.-T. and A.V.-O. wrote the Results and prepared figures and tables. Discussions and Conclusions were the collective work of all authors. The writing-review \& editing was performed by A.D.G.-D.

Funding: This research was funded by University of Cartagena with the grant of "Viceinvestigaciones" Program and The APC was also funded by University of Cartagena.

Acknowledgments: Authors would like to thank University of Cartagena for proving the chemicals and equipment required to successfully conclude this work.

Conflicts of Interest: The authors declare no conflict of interest.

\section{References}

1. Romero-Cano, L.A.; García-Rosero, H.; Gonzalez-Gutierrez, L.V.; Baldenegro-Pérez, L.A.; Carrasco-Marín, F. Functionalized adsorbents prepared from fruit peels: Equilibrium, kinetic and thermodynamic studies for copper adsorption in aqueous solution. J. Clean. Prod. 2017, 162, 195-204. [CrossRef]

2. Iqbal, M.; Abbas, M.; Nisar, J.; Nazir, A.; Qamar, A.Z. Bioassays based on higher plants as excellent dosimeters for ecotoxicity monitoring: A review. Chem. Int. 2019, 5, 1-80.

3. Iqbal, M. Vicia faba bioassay for environmental toxicity monitoring: A review. Chemosphere 2016, 144, 785-802. [CrossRef]

4. Zaidi, N.A.H.M.; Lim, L.B.L.; Usman, A. Enhancing adsorption of $\mathrm{Pb}(\mathrm{II})$ from aqueous solution by $\mathrm{NaOH}$ and EDTA modified Artocarpus odoratissimus leaves. J. Environ. Chem. Eng. 2018, 6, 7172-7184. [CrossRef]

5. Neris, J.B.; Luzardo, F.H.M.; da Silva, E.G.P.; Velasco, F.G. Evaluation of adsorption processes of metal ions in multi-element aqueous systems by lignocellulosic adsorbents applying different isotherms: A critical review. Chem. Eng. J. 2019, 357, 404-420. [CrossRef]

6. Abbas, M.; Adil, M.; Ehtisham-ul-Haque, S.; Munir, B.; Yameen, M.; Ghaffar, A.; Abbas, G.; Asif, M.; Iqbal, M. Vibrio fischeri bioluminescence inhibition assay for ecotoxicity assessment: A review. Sci. Total Environ. 2018, 626, 1295-1309. [CrossRef] [PubMed]

7. Hasan, R.; Bukhari, S.N.; Jusoh, R.; Mutamin, N.S.A.; Setiabudi, H.D. Adsorption of Pb(II) onto KCC-1 from aqueous solution: Isotherm and kinetic study. Mater. Today Proc. 2018, 5, 21574-21583. [CrossRef]

8. Chen, Y.; Wang, H.; Zhao, W.; Huang, S. Four different kinds of peels as adsorbents for the removal of Cd (II) from aqueous solution: Kinetics, isotherm and mechanism. J. Taiwan Inst. Chem. Eng. 2018, 88, 146-151. [CrossRef]

9. Liu, Y.; Sun, $\mathrm{X}$.; Li, B. Adsorption of $\mathrm{Hg} 2+$ and $\mathrm{Cd} 2+$ by ethylenediamine modified peanut shells. Carbohydr. Polym. 2010, 81, 335-339. [CrossRef]

10. Kang, R.; Qiu, L.; Fang, L.; Yu, R.; Chen, Y.; Lu, X.; Luo, X. A novel magnetic and hydrophilic ion-imprinted polymer as a selective sorbent for the removal of cobalt ions from industrial wastewater. Biochem. Pharmacol. 2016, 4, 2268-2277. [CrossRef]

11. Moreno-Sader, K.; García-Padilla, A.; Realpe, A.; Acevedo-Morantes, M.; Soares, J. Removal of Heavy Metal Water Pollutants (Co2+ and Ni2+) Using Polyacrylamide/Sodium Montmorillonite (PAM/Na-MMT) Nanocomposites. ACS Omega 2019, 4, 10834-10844. [CrossRef] [PubMed]

12. Liang, S.; Guo, X.; Feng, N.; Tian, Q. Isotherms, kinetics and thermodynamic studies of adsorption of Cu2+ from aqueous solutions by Mg2+/K+ type orange peel adsorbents. J. Hazard Mater. 2010, 174, 756-762. [CrossRef] [PubMed]

13. Liang, X.; Wei, G.; Xiong, J.; Tan, F.; He, H.; Qu, C.; Yin, H.; Zhu, J.; Zhu, R.; Qin, Z.; et al. Adsorption isotherm, mechanism, and geometry of $\mathrm{Pb}$ (II) on magnetites substituted with transition metals. Chem. Geol. 2017, 470, 132-140. [CrossRef] 
14. Villabona-Ortiz, A.; Tejada-Tovar, C.; Gonzalez-Delgado, A.; Herrera-Barros, A.; Cantillo-Arroyo, G. Immobilization of Lead and Nickel Ions from Polluted Yam Peels Biomass Using Cement-Based Solidification/Stabilization Technique. Int. J. Chem. Eng. 2019, 2019, 5413960. [CrossRef]

15. Anastopoulos, I.; Pashalidis, I.; Hosseini-Bandegharaei, A.; Giannakoudakis, D.; Robalds, A.; Usman, M.; Belen, L.; Zhou, Y.; Colmenares, J.; Núñez-Delgado, A.; et al. Agricultural biomass/waste as adsorbents for toxic metal decontamination of aqueous solutions. J. Mol. Liq. 2019, 111684. [CrossRef]

16. Di Bitondo, L.; Volpe, A.; Pagano, M.; Bagnuolo, G.; Mascolo, G.; La Parola, V.; Di leo, P.; Pastore, C. Amorphous boron-doped sodium titanates hydrates: Efficient andreusable adsorbents for the removal of Pb2+from water. J. Hazard Mater. 2017, 324, 168-177. [CrossRef]

17. Huang, J.; Cao, Y.; Liu, Z.; Deng, Z.; Tang, F.; Wang, W. Efficient removal of heavy metal ions from water system by titanate nanoflowers. Chem. Eng. J. 2012, 180, 75-80. [CrossRef]

18. Hu, J.; Shipley, H.J. Regeneration of spent $\mathrm{TiO} 2$ nanoparticles for $\mathrm{Pb}$ (II), $\mathrm{Cu}$ (II), and $\mathrm{Zn}$ (II) removal. Environ. Sci. Pollut. Res. 2013, 20, 5125-5137. [CrossRef]

19. Hu, J.; Shipley, H.J. Evaluation of desorption of $\mathrm{Pb}$ (II), $\mathrm{Cu}$ (II) and $\mathrm{Zn}$ (II) from titanium dioxide nanoparticles. Sci. Total. Environ. 2012, 431, 209-220. [CrossRef]

20. Boeykens, S.; Redondo, N.; Alvarado, R.; Caracciolo, N.; Vazquez, C. Chromium and Lead adsorption by avocado seed biomass study through the use of Total Reflection X-Ray Fluorescence analysis. Appl. Radiat. Isot. 2019, 153, 108809. [CrossRef]

21. Amin, M.; Alazba, A.; Shafiq, M. Application of biochar derived from date palm biomass for removal of lead and copper ions in a batch reactor: Kinetics and isotherm scrutiny. Chem. Phys. Lett. 2019, 722, 64-73. [CrossRef]

22. Bagali, S.; Gowrishankar, B.; Roy, A. Optimization, Kinetics, and Equilibrium Studies on the Removal of Lead(II) from an Aqueous Solution Using Banana Pseudostem as an Adsorbent. Engineering 2017, 3, 409-415. [CrossRef]

23. Alhogbi, B. Potential of coffee husk biomass waste for the adsorption of $\mathrm{Pb}$ (II) ion from aqueous solutions. Sustain. Chem. Pharm. 2017, 6, 21-25. [CrossRef]

24. Mohammed, A.; Khalifa, A.; Muftah, K. Removal of $\mathrm{Pb}(\mathrm{II}), \mathrm{Zn}(\mathrm{II}), \mathrm{Cu}(\mathrm{II})$ and $\mathrm{Cd}(\mathrm{II})$ from aqueous solutions by adsorption onto olive branches activated carbon: Equilibrium and thermodynamic studies. Chem. Int. 2020, 6, 11-20, in press.

25. Tejada, C.N.; Montiel, Z.; Acevedo, D. Aprovechamiento de Cáscaras de Yuca y Name para el Tratamiento de Aguas Residuales Contaminadas con Pb(II). Inf. Tecnol. 2016, 27, 9-20. [CrossRef]

26. Tejada-Tovar, C.; Ruiz-Paternina, E.; Gallo-Mercado, J.; Moscote-Bohorquez, J. Evaluación de la biosorción con bagazo de palma africana para la eliminación de $\mathrm{Pb}$ (II) en solución Evaluation of the biosorption with african palm bagasse for the removal of $\mathrm{Pb}$ (II) in solution. Rev. Prospect. 2015, 13, 59-67. [CrossRef]

27. Tejada-Tovar, C.; Tejeda, L.; Marimón, W.; Villabona-Ortíz, A. Estudio de modificación química y física de biomasa (Citrus sinensis y Musa paradisiaca) para la adsorción de metales pesados en solución. Rev. Luna Azul 2014, 39, 124-142. [CrossRef]

28. Singh, H.; Sapra, P.K.; Sidhu, B.S. Evaluation and Characterization of Different Biomass Residues through Proximate \& Ultimate Analysis and Heating Value. Asian J. Eng. Appl. Technol. 2013, 2, 6-10.

29. Sherlala, A.I.A.; Raman, A.A.A.; Bello, M.M.; Asghar, A. A review of the applications of organo-functionalized magnetic graphene oxide nanocomposites for heavy metal adsorption. Chemosphere 2018, 193, 1004-1017. [CrossRef] [PubMed]

30. Tejada-Tovar, C.; Montiel-Rodríguez, Z.P.; Nieto-Muñoz, Y. Estudio de la Adsorción Competitiva de Pb+2 y $\mathrm{Ni}+2$ Usando Cáscara de Yuca (Manihot Esculenta) Modificada Con ácido Cítrico. Ph.D. Thesis, University of Cartagena, Cartagena, Bolívar, Colombia, 2014; pp. 1-55.

31. Janyasuthiwong, S.; Phiri, S.M.; Kijjanapanich, P.; Rene, E.R.; Esposito, G.; Lens, P.N.L. Copper, lead and zinc removal from metal-contaminated wastewater by adsorption onto agricultural wastes. Environ. Technol. 2015, 36, 3071-3083. [CrossRef]

32. Abdolali, A.; Ngo, H.H.; Guo, W.; Zhou, J.L.; Zhang, J.; Liang, S.; Chang, S.W.; Nguyen, D.D.; Liu, Y. Application of a breakthrough biosorbent for removing heavy metals from synthetic and real wastewaters in a lab-scale continuous fixed-bed column. Bioresour. Technol. 2017, 229, 78-87. [CrossRef] [PubMed] 
33. Šoštarić, T.D.; Petrović, M.S.; Pastor, F.T.; Lončarević, D.R.; Petrović, J.T.; Milojković, J.V.; Stojanović, M.D. Study of heavy metals biosorption on native and alkali-treated apricot shells and its application in wastewater treatment. J. Mol. Liq. 2018, 259, 340-349. [CrossRef]

34. Lawal, O.S.; Ayanda, O.S.; Rabiu, O.O.; Adebowale, K.O. Application of black walnut (Juglans nigra) husk for the removal of lead (II) ion from aqueous solution. Water Sci. Technol. 2017, 75, 2454-2464. [CrossRef] [PubMed]

35. Asuquo, E.D.; Martin, A.D. Sorption of cadmium (II) ion from aqueous solution onto sweet potato (Ipomoea batatas L.) peel adsorbent: Characterisation, kinetic and isotherm studies. J. Environ. Chem. Eng. 2016, 4, 4207-4228. [CrossRef]

36. Asuquo, E.; Martin, A.; Nzerem, P.; Siperstein, F.; Fan, X. Adsorption of Cd(II) and Pb(II) ions from aqueous solutions using mesoporous activated carbon adsorbent: Equilibrium, kinetics and characterisation studies. J. Environ. Chem. Eng. 2017, 5, 679-698. [CrossRef]

37. Berhe, S.; Ayele, D.; Tadesse, A.; Mulu, A. Adsorption Efficiency of Coffee Husk for Removal of Lead (II) from Industrial Effluents: Equilibrium and Kinetic Study. Int. J. Sci. Res. Publ. 2015, 5, 753-859.

38. Yin, W.; Zhao, C.; Xu, J.; Zhang, J.; Guo, Z.; Shao, Y. Removal of Cd(II) and Ni(II) from aqueous solutions using activated carbon developed from powder-hydrolyzed-feathers and Trapa natans husks. Coll. Surf. A Physicochem. Eng. Asp. 2019, 560, 426-433. [CrossRef]

39. Fernandez, M.E.; Ledesma, B.; Román, S.; Bonelli, P.R.; Cukierman, A.L. Development and characterization of activated hydrochars from orange peels as potential adsorbents for emerging organic contaminants. Bioresour. Technol. 2015, 183, 221-228. [CrossRef]

40. Pradhan, P.; Arora, A.; Mahajani, S.M. Pilot scale evaluation of fuel pellets production from garden waste biomass. Energy Sustain. Dev. 2018, 43, 1-14. [CrossRef]

41. Singh, S.A.; Shukla, S.R. Adsorptive removal of cobalt ions on raw and alkali-treated lemon peels. Int. J. Environ. Sci. Technol. 2016, 13, 165-178. [CrossRef]

42. Medellin-Castillo, N. Bioadsorción de plomo (II) presente en solución acuosa sobre residuos de fibras naturales procedentes de la industria ixtlera (Agave lechuguilla Torr. y Yucca carnerosana (TREL.) MCKELVEY). Rev. Int. Contam. Ambient. 2017, 33, 269-280. [CrossRef]

43. Gupta, A.; Balomajumder, C. Journal of Water Process Engineering Simultaneous removal of Cr (VI) and phenol from binary solution using Bacillus sp. immobilized onto tea waste biomass. J. Water Process Eng. 2015, 6, 1-10. [CrossRef]

44. Castro, L.; Blázquez, M.L.; González, F.; Muñoz, J.A.; Ballester, A. Heavy metal adsorption using biogenic iron compounds. Hydrometallurgy 2018, 179, 44-51. [CrossRef]

45. De Melo, N.H.; de Oliveira Ferreira, M.E.; Silva Neto, E.M.; Martins, P.R.; Ostroski, I.C. Evaluation of the adsorption process using activated bone char functionalized with magnetite nanoparticles. Environ. Nanotechnol. Monit. Manag. 2018, 10, 427-434. [CrossRef]

46. Obike, A.I.; Igwe, J.C.; Emeruwa, C.N.; Uwakwe, K.J. Equilibrium and kinetic studies of Cu (II), Cd (II), $\mathrm{Pb}$ (II) and $\mathrm{Fe}$ (II) adsorption from aqueous solution using cocoa (Theobroma cacao) pod husk. J. Appl. Sci. Environ. Manag. 2018, 22, 182-190. [CrossRef]

47. Raikar, R.V.; Correa, S.; Ghorpade, P. Removal of lead (II) from aqueous solution using natural and activated rice husk. Int. Res. J. Eng. Technol. 2015, 2, 1677-1686.

48. Villabona-Ortíz, A.; Tejada-Tovar, C.; Gonzalez-Delgado, A. Application of cement-based solidification/ stabilization technique for immobilizing lead and nickel ions after sorption-desorption cycles using cassava peels biomass. Indian J. Sci. Technol. 2018, 11, 1-6. [CrossRef]

(C) 2019 by the authors. Licensee MDPI, Basel, Switzerland. This article is an open access article distributed under the terms and conditions of the Creative Commons Attribution (CC BY) license (http://creativecommons.org/licenses/by/4.0/). 